\title{
ISOLATION OF MULTI-DRUG RESISTANT POTENTIAL PATHOGENIC BACTERIA FROM BLOW FLY COLLECTED FROM DIFFERENT AREAS OF DHAKA CITY
}

\author{
Tangin Akter*, Samira Jahan, Sangita Ahmed ${ }^{1}$, \\ Shanjida Sultana and Shefali Begum \\ Department of Zoology, Faculty of Biological Sciences, University of Dhaka, \\ Dhaka-1000, Bangladesh
}

\begin{abstract}
The research work was conducted for isolation and identification of potential pathogenic bacteria from blow fly (Calliphora spp.) and to investigate their antibiotic susceptibility. For this purpose, 20 blow flies were collected from 4 selected areas (Curzon Hall, Dhaka Medical College Hospital, Fruit Store and Fish Market) of Dhaka city. A total of 40 samples (20 from external surface and 20 from alimentary gut homogenates) were prepared from the blow flies. Among the total 20 flies, 3(15\%) were collected from Curzon Hall and 5(12.5\%) isolates were obtained from them; $6(30 \%)$ flies were collected from $\mathrm{DMCH}$ which had $11(27.5 \%)$ isolates; $5(25 \%)$ flies were collected from fruit stores and $10(25 \%)$ isolates were collected from there; $6(30 \%)$ flies were collected from fish market and $14(35 \%)$ isolates were collected from there. The isolated bacteria were presumptively identified as Escherichia coli, 12 (30\%); Salmonella spp., 8 (20\%); Shigella spp., 4(10\%); Enterobacter spp., 3 (7.5\%); Klebsiella spp., 2 (5\%); Bacillus spp., 7 $(17.5 \%)$ and Staphylococcus spp., $4(10 \%)$ in number which were based on morphology as observed under microscope as well as cultural and biochemical properties. All of these isolates were resistant to various antibiotics. Bacterial susceptibility showed that $E$. coli isolates were highly resistant (66.6\%) to Penicillin, Salmonella spp. mostly resistant (62.5\%) to Penicillin and Tetracycline. Klebsiella spp. Isolates were $100 \%$ resistant to Penicillin and $100 \%$ sensitive to Ciprofloxacin, Imipenem and Tetracycline. In case of Shigella spp. and Enterobacter spp., $75 \%$ and $100 \%$ isolates were resistant to Penicillin respectively. Among the Staphylococcus spp. isolates, $75 \%$ were resistant to Ampicillin and Penicillin. In case of Bacillus spp. isolates, 57.2\% were resistant to Penicillin and $100 \%$ sensitive to Imipenem. Antibiotic resistance of these species affect our human health also. This study demonstrated the potential of blow flies as a vector of various pathogenic microorganisms and a mode of transmission of antibiotic resistance.
\end{abstract}

Key words: Blow fly, Pathogenic bacteria, Antibiotic susceptibility, Dhaka city

\footnotetext{
* Author for corresponding: <aktert1@yahoo.com>, 1Department of Microbiology, Faculty of Biological sciences, University of Dhaka, Dhaka-1000, Bangladesh

CO2021 Zoological Society of Bangladesh DOI: https://doi.org/10.3329/bjz.v49i2.56258
} 


\section{INTRODUCTION}

The blow fly (Family: Calliphoridae) is a dipteran fly. It is one of the most abundant and common flies in our surroundings and serving as vector for some of the diseases affecting humans (Pava-Ripoll et al., 2012). It is widely distributed insect and found all over the world. Calliphora is the most common genus in Bangladesh. Most of the blow flies are active in day time and very few are nocturnal. The adult females are nuisance pests. They bustle around in houses searching for places or medium to lay their eggs. They breed in garbage and moist, dirty places. They are carriers of various important microorganisms (Banjo et al., 2006). From many points of view blow flies are considered medically important insects. Adult flies vex humans and economically important animals (Sukontason et al., 2007). This species is considered as the mechanical conveyor of various pathogens (Monzon et al. 1991; Maldonado and Centeno 2003; Sukontason et al. 2007) and can cause myiasis (Kumarasinghe et al. 2000). It can be a general interior trouble (Greenberg 1971). Flies have the ability to transmit pathogens between different environments. They play as one of the most important vectors of human diseases worldwide (Zhang et al., 2017). Many researchers have studied that specimens of blow fly are found associated with cases of human death (Lee 1996; Carvalho et al. 2000; Lee et al. 2004; Sukontason et al. 2005).Blow flies have been found to propagate the etiological agents of typhoid and paratyphoid fevers, bacillary dysentery, cholera, hematic carbuncles, bovine mastitis (garget), conjunctivitis and poliomyelitis (Greenberg, 1971). These fly species have also been recorded capable of carrying cysts of many protozoans, such as Entamoeba histolytica, Entamoeba coli, Giardia intestinalis and the eggs of some helminthes (Sales et al., 2002). Multi-drug resistance (MDR) has become a serious problem for the treatment of human infections. Several insects like flies, cockroaches have been reported to carry multi-drug resistant bacteria, thereby aiding in transmission of these bacteria as well as drug resistance genes among bacterial population as well as from bacteria to human and other animals (Akter et al., 2017). Though the blow flies are very abundant in Dhaka city, there is not have enough information about their role as mechanical transmitters of pathogenic bacteria.

\section{MATERIAL AND METHODS}

The study was conducted in Entomology Laboratory, Department of Zoology and Microbiology Laboratory, Department of Microbiology, University of Dhaka. 
To collect blow flies four specific locations were selected. The locations were Curzon Hall, Dhaka Medical College Hospital (DMCH), Fruit stores and Fish Market of Ananda Bazar.

The flies were collected by sterilizing insect net and hand picking. For microbial process, blow flies were collected using sterile screw capped jar. Inside the jar there was some cotton which was mixed with chloroform for anesthetizing. Collected blowflies were placed into the sterile tube individually inflicting minimal injury to them. Identification was made by examining the fly inside test tube under a dissecting microscope and following standard taxonomic keys (Gupta et al., 2011). After identification, $9 \mathrm{ml}$ of sterile saline (0.85\%) was added to the tube containing blow flies. And the fly was thoroughly shaken for two minutes in the vortex machine. The wash was taken as external body homogenate sample (Fotedar et al., 1992). After external body washing, the flies were soaked in $70 \%$ ethanol for five minutes to decontaminate their external surface and dried, followed by washing with sterile saline to remove traces of ethanol. The alimentary tract of flies was aseptically dissected out using autoclaved sterilized entomological dissecting needles under a dissecting microscope. The instrument was dipped in ethanol and flamed between dissections. The excised gut was homogenized in $9 \mathrm{ml}$ of sterile normal saline water. Then it was diluted.

Twenty blow flies were collected for the experiment. From there a total of 40 samples consisting of 20 external body surface and 20 gut homogenates were analyzed. All collected homogenate were cultured by using spread plate technique into Nutrient Agar (NA) media and M-FC media followed by incubation at $37^{\circ} \mathrm{C}$ for 24 hours. Growth on all plates were observed and the number of bacteria colonies were counted. To obtain pure culture, isolated colonies were subcultured on NA media. To identify the presence of potentially pathogenic bacteria, the samples were also subcultured on Mac Conkey media and Mannitol salt agar. Morphological properties of colonies (size, shape, elevation, color, consistency, opacity, pigmentation) developed after incubation on Mac Conkey, M-FC and MSA agar plates were carefully studied and recorded.

Gram staining was accomplished to determine the size, shape, arrangement and gram reaction to isolated organisms. The steps were followed by Pelczar et al. (1993).

The presumptive identification of isolates was done by performing various biochemical tests. For Gram-negative bacteria motility test, indole test, citrate utilization test, lactose fermentation test and glucose fermentation test in Kingler's Iron Agar (KIA) were performed. For Gram-positive bacteria catalase 
test and oxidase test were performed. All the tests were accomplished by following the standard protocol as described in Bergey's Manual of Systematic Bacteriology (Garrity, 2001).

Antibiotic susceptibility testing of bacterial isolates was done by Kirby Bauer disk diffusion method using Mueller Hinton Agar (MHA) plate. Commercial antimicrobial discs were used which include: Ampicillin (AMP 25), Penicillin-G (P), Chloramphenicol (C), Tetracycline (TE), Ciprofloxacin (CIP), Amoxicillin (AML), Imipenem (IMI), Erythromycin (E).

\section{RESULTS AND DISCUSSION}

Bacteriological characteristics of 20 blow flies were investigated. A total of 40 samples were prepared from the blow flies.

Among the total 20 flies, 3(15\%) were collected from Curzon Hall and 5(12.5\%) isolates were obtained from them; 6(30\%) flies were collected from DMCH which had $11(27.5 \%)$ isolates; $5(25 \%)$ flies were collected from fruit stores and $10(25 \%)$ isolates were collected from there; 6(30\%) flies were collected from fish market and $14(35 \%)$ isolates were collected from there (Table-1).

Table 1: Distribution of collected flies and their isolates

\begin{tabular}{lcccr}
\hline Name of place & $\begin{array}{l}\text { Number } \\
\text { Fly }\end{array}$ & $\begin{array}{l}\text { of } \\
\text { of Fly }\end{array}$ & $\begin{array}{l}\text { Number of } \\
\text { isolates }\end{array}$ & $\begin{array}{l}\text { Percentage } \\
\text { of isolates }\end{array}$ \\
\hline Curzon hall & 3 & $15 \%$ & 5 & $12.50 \%$ \\
DMCH & 6 & $30 \%$ & 11 & $27.50 \%$ \\
Fruit store & 5 & $25 \%$ & 10 & $25 \%$ \\
Fish Market & 6 & $30 \%$ & 14 & $35 \%$ \\
Total & 20 & $100 \%$ & 40 & $100 \%$ \\
\hline
\end{tabular}

Among the 40 isolates $19(47 \%)$ were collected from the external surface and $21(53 \%)$ from the alimentary gut. Based on biochemical tests and growth on selective media the isolates were presumptively identified as E. coli (30\%), Salmonella spp. (20\%), Bacillus spp. (17.5\%), Shigella spp. (10\%), Staphylococcus spp. (10\%), Enterobacter spp. (7.5\%) and Klebsiella spp. (5\%) (Table 2). It was observed that $47 \%$ bacteria was isolated from external body surface and 21 (53\%) bacteria was isolated from gut. Among them Klebsiella was found only on the body surface, Shigella and Enterobacter was found only in the gut and the rest of the bacterial species was isolated from both external body surface and gut. Seven types of bacteria species were isolated in which 5 (E.coli, Enterobacter, Salmonella, Shigella, Klebsiella) were Gram-negative while the other 2 (Bacillus and Staphylococcus) were Gram-positive bacteria. Among the isolated Gram-negative bacteria, E. coli was the most dominant and among the 
Table 2: Percentage of different bacteria between external surface and gut

\begin{tabular}{|c|c|c|c|c|c|}
\hline \multicolumn{2}{|c|}{ Name of bacteria isolates } & \multicolumn{2}{|c|}{ Number of bacteria } & Total & Percentage \\
\hline \multirow{6}{*}{ Gram negative } & E. coli & 6 & 6 & 12 & $30.00 \%$ \\
\hline & Klebsiella spp. & 2 & 0 & 2 & $5 \%$ \\
\hline & Salmonella spp. & 5 & 3 & 8 & $20.00 \%$ \\
\hline & Shigella spp. & 0 & 4 & 4 & $10 \%$ \\
\hline & Enterobacter spp. & 0 & 3 & 3 & $7.50 \%$ \\
\hline & Bacillus spp. & 5 & 2 & 7 & $17.50 \%$ \\
\hline Gram positive $\backslash \backslash$ & $\begin{array}{l}\text { Staphylococcus } \\
\text { spp. }\end{array}$ & 1 & 3 & 4 & $10 \%$ \\
\hline Total & & $19(47 \%)$ & $21(53 \%)$ & 40 & $100 \%$ \\
\hline
\end{tabular}

Gram-positive, Bacillus spp. was higher in number (Table 3, Table 4). Most of these bacteria are associated with diseases in human. E.coli, Enterobacter, Salmonella, Shigella, Klebsiella are commonly associated with infections of the intestinal tract, while Staphylococcus aureus can cause skin infection and food poisoning(Forster et al., 2009). Bacillus cereus also causes diarrhea (Chen et al., 2019; Thirkell et al., 2018). Haghi et al., (2018) and Humphrey et al., (2007) similarly showed that the house flies carried bacteria on their external body surface as well as inside the body. According to Akter et al., 2017 and Graczyk et al., 2001, filth flies such as Sarcophagidae, Calliphoridae and Muscidae played important roles in the transmission of human and animal pathogens. These insects were closely associated with animals, humans and their food stuffs. The current study also showed that blow flies carried different bacterial pathogens. So far, human pathogenic bacteria are not reported to multiply in blow flies, suggesting that these flies act as mechanical vectors, rather than being involved in biological transmission of pathogens. Identified isolates were tested for their antibiotic susceptibility against eight commonly used antibiotics. The diffusion zone breakpoints recommended by Clinical and Laboratory Standards Institute (CLSI) guidelines for Staphylococcus aureus ATCC 25923 and Escherichia coli ATCC 25922 were used and the isolates were categorized to Sensitive (S), Intermediate (I) or Resistant (R) (Limbago, 2001). Most of the E. coli isolates were resistant to those antibiotics. The highest resistance pattern (66.6\%) was found against Penicillin and the lowest (33.3\%) was found against Chloramphenicol antibiotic. It was found that 100\% Klebsiella $s p p$. were sensitive to Ciprofloxacin, Imipenem and Tetracycline, while all of them were resistant to Penicillin. Among the Salmonella spp. isolates, highest (87.5\%) susceptibility was observed to Chloramphenicol and highest (62.5\%) resistance was found against Tetracycline and Penicillin. Among 4 isolates of 
Table 3: Biochemical test result of Gram-negative isolates collected from 4 selected areas

\begin{tabular}{|c|c|c|c|c|c|c|c|c|c|c|}
\hline \multirow{3}{*}{$\begin{array}{l}\text { Study } \\
\text { area }\end{array}$} & \multirow[t]{3}{*}{ Isolate no. } & \multirow[t]{3}{*}{ Gram stain } & \multicolumn{7}{|c|}{ Biochemical test } & \multirow{3}{*}{$\begin{array}{l}\text { Presumptive } \\
\text { Identification }\end{array}$} \\
\hline & & & \multicolumn{4}{|c|}{ Kingler's Iron Agar Test } & \multirow{2}{*}{ 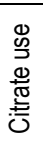 } & \multirow{2}{*}{ 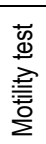 } & \multirow{2}{*}{ 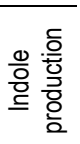 } & \\
\hline & & & 芯 & $\frac{\dot{0}}{0}$ & $\stackrel{\mathscr{N}}{\mathbb{N}}$ & $\stackrel{\mathscr{N}}{\text { I }}$ & & & & \\
\hline Curzon & $C-1,4$ & Gram-negative rod & + & + & - & - & + & - & + & Salmonella spp. \\
\hline \multirow[t]{4}{*}{ Hall } & $C-3,5$ & Gram-negative rod & + & + & + & - & - & - & + & E. coli \\
\hline & $C-$ & Gram-negative rod & + & + & + & - & - & + & - & E. coli \\
\hline & $6,11,12,16$ & & & & & & & & & \\
\hline & C - 9 & Gram-negative rod & + & + & - & - & + & - & + & Klebsiella spp. \\
\hline \multirow[t]{4}{*}{$\mathrm{DMCH}$} & C - 10,15 & Gram-negative rod & - & - & - & - & + & + & - & Salmonella spp. \\
\hline & $C-13$ & Gram-negative rod & - & + & - & - & - & - & - & Shigella spp. \\
\hline & C - $17,21,23$ & Gram-negative rod & + & + & + & - & - & + & - & E. coli \\
\hline & C - 18,22 & Gram-negative rod & - & + & - & - & + & + & - & Enterobacter spp. \\
\hline Fruit & C - 19,24 & Gram-negative rod & + & - & - & - & + & + & - & Salmonella spp. \\
\hline \multirow[t]{5}{*}{ Store } & $C-26$ & Gram-negative rod & + & + & - & - & - & - & + & Shigella spp. \\
\hline & $C-28$ & Gram-negative rod & + & + & - & - & + & + & - & Enterobacter spp. \\
\hline & C - 30,37 & Gram-negative rod & - & + & - & - & - & + & + & Salmonella spp. \\
\hline & C - $31,36,38$ & Gram-negative rod & + & + & + & - & - & + & + & E. coli \\
\hline & C - 39 & Gram-negative rod & - & + & - & - & + & - & + & Klebsiella spp. \\
\hline $\begin{array}{l}\text { FISn } \\
\text { Market }\end{array}$ & C - 33,40 & Gram-negative rod & - & - & - & - & - & - & - & Shigella spp. \\
\hline
\end{tabular}

Table 4: Biochemical test result of Gram-positive isolates collected from 4 selected areas

\begin{tabular}{cllccl}
\hline Study area & Isolate no. & Gram stain & \multicolumn{2}{c}{ Biochemical test } & \multicolumn{1}{c}{$\begin{array}{c}\text { Presumptive } \\
\text { Identification }\end{array}$} \\
\cline { 4 - 5 } & & & Catalase & Oxidase & \multicolumn{1}{c}{} \\
\hline Curzon Hall & C -2 & Gram-positive rod & + & - & Bacillus spp. \\
DMCH & C -7 & Gram-positive rod & + & + & Bacillus spp. \\
& C $-8,14$ & Gram-positive cocci & + & - & Staphylococcus spp. \\
Fruit Store & C -20 & Gram-positive cocci & + & - & Staphylococcus spp. \\
& C -25 & Gram-positive rod & + & - & Bacillus spp. \\
Fish Market & C $-27,32,34,35$ & Gram-positive rod & + & + & Bacillus spp. \\
& C -29 & Gram-positive cocci & + & - & Staphylococcus spp. \\
\hline
\end{tabular}

Shigella spp. most of them were resistant (75\%) against Penicillin and mostly sensitive $(75 \%)$ to Tetracycline (Table-5). 


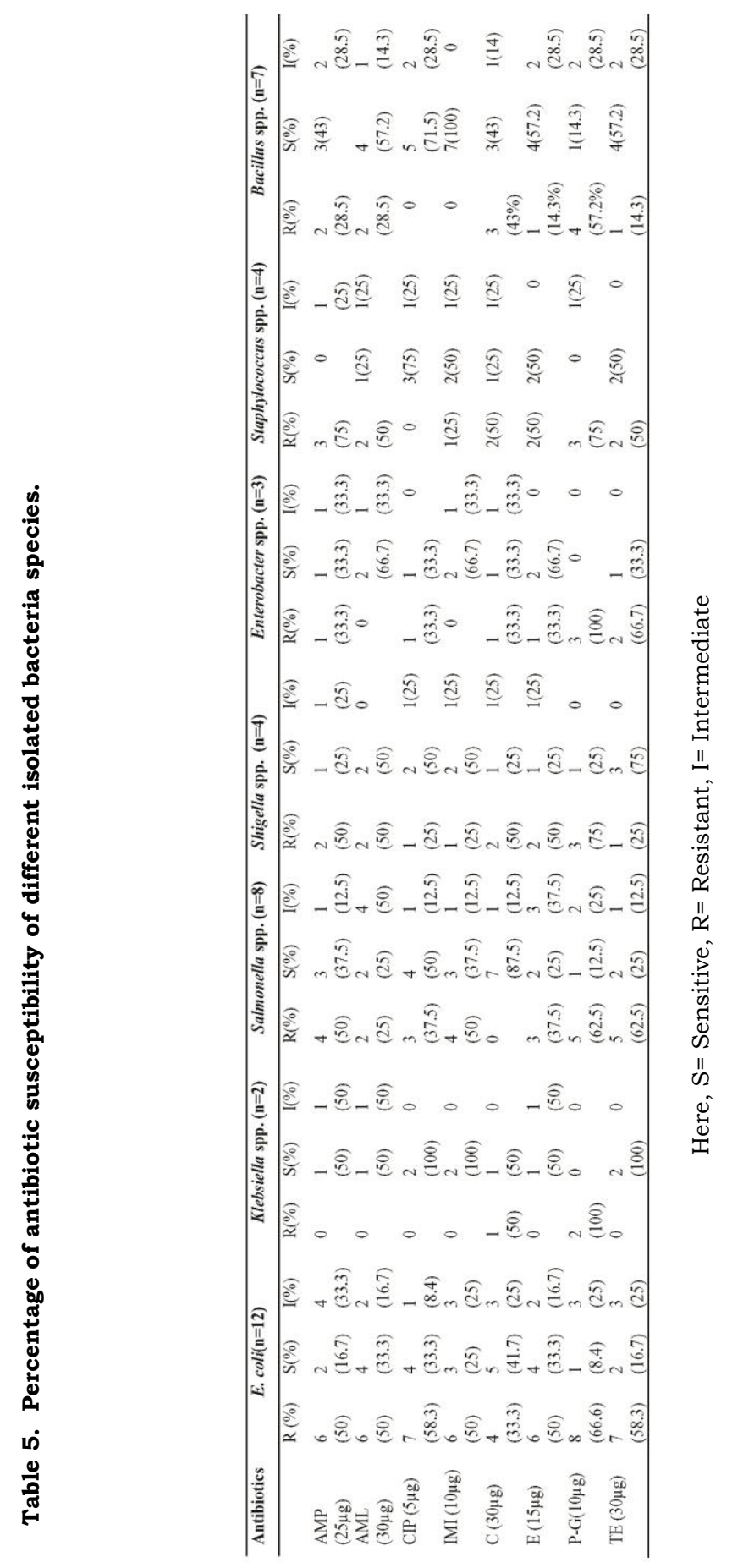


It was observed that, 3 isolates of Enterobacter spp. were equally susceptible and resistant against these antibiotics. All of the 3 isolates (100\%) were resistant against Penicillin antibiotic. Most of the isolates of Staphylococcus spp. were resistant. Among them, they were mostly resistant (75\%) against Penicillin and most susceptible $(75 \%)$ to Ciprofloxacin antibiotic. It was found that most of the isolates of Bacillus spp. were sensitive to these antibiotics. Among these all of the isolates (100\%) were susceptible to Imipenem antibiotic (Table-5). Pai et al., (2005) isolated similar antibiotic resistant pathogenic bacteria such as $S$. aureus, Enterococcus spp., P. aeruginosa, K.pneumoniae, E. coli, S. marcescens, and Proteus species isolated from household cockroaches. To further understand the significance of the presence of these multi-drug resistant bacteria in blow fly, it is important to investigate how long these pathogens remain viable on the fly or whether these antibiotic resistance genes are located on mobile genetic elements like plasmids, which would increase the chance of spreading the resistance.

It is also worth investigating whether the antibiotic resistant bacteria in blow flies have any impact on the normal microflora present in the flies or on the life cycle of these insects.

The presence of antibiotic resistant potential human pathogens in blow fly observed in the current study is alarming and a serious public health concern. Reduced effectiveness of antibiotics results in greater patient mortality rates, prolonged hospitalization and increased health care cost. It is therefore essential to take suitable steps to control the bow flies and to regularly monitor the presence of the multi-drug resistant human pathogens in these flies.

\section{LITERATURE CITED}

AKTER, T., AHMED, S., and DAS, B. 2017. Carriage of multi-drug resistant Gram-negative pathogenic bacteria by the house fly Musca domestica. Dhaka Univ. J. Biol. Sci. 26(1): 91-99.

BANJO, A. D., LAWAL, O. A., and AKINTOLA, O. I. 2006. Bacteria and fungi associated with Luciliacuprina (sheep blowfly) larvae. Res. J. Agri. \& Biol. Sci. 2(6):358-364.

CARVAlho, L. M. L. D., ThYSSEn, P. J., LinhaRes, A. X., and PAlHARES, F. A. B. 2000. A checklist of arthropods associated with pig carrion and human corpses in Southeastern Brazil. Mem. Inst. Oswaldo Cruz. 95(1):135-138.

CHEN, D., LI, Y., LV, J., LIU, X., GAO, P., ZHEN, G., ZHANG, W., WU, D., JING, H., LI, Y., ZHAO, Y., MA, X., MA, H., and ZHANG, L. 2019. A foodborne outbreak of gastroenteritis caused by Norovirus and Bacillus cereus at a university in the Shunyi District of Beijing, China 2018: a retrospective cohort study. BMC Infect Dis. 19(1):910. 
FÖRSTER, M., SIEVERT, K., MESSLER, S., KLIMPEL, S., and PFEFFER, K. 2009.Comprehensive study on the occurrence and distribution of pathogenic microorganisms carried by synanthropic flies caught at different rural locations in Germany. J. Med. Entomol. 46(5):11641166.

FOTEDAR, R., BANERJEE, U., SINGH, S., and VERMA, A. K. 1992. The housefly (Musca domestica) as a carrier of pathogenic microorganisms in a hospital environment. J. hospital infect. 20(3): 209-215.

GARRITY, G.M., BOONE, D.R. and CASTENHOLZ, R.W. 2001. Bergey's Manual of Systematic Bacteriology. Springer-Verlag, New York, NY. 2(1)

GRACZYK, T. K., KNIGHT, R., GILMAN, R. H., and CRANFIELD, M. R. 2001. The role of non-biting flies in the epidemiology of human infectious diseases. Microb. \& infect.3(3):231-235.

GREENBERG, B. 1971.Flies and disease. Vol.1: Ecology, classification and biotic associations. Princeton: Princeton Univ. Press. pp. 1-856.

GUPTA, A. K., DHARNE, M. S., RANGREZ, A. Y., VERMA, P., GHATE, H. V., ROHDE, M., and SHOUCHE, Y. S. 2011. Ignatzschineria indica sp. nov. and Ignatzschineria ureiclastica sp. nov., isolated from adult flesh flies (Diptera: Sarcophagidae). Int. J. Syst.Evol. Microbiol. 61(6):13601369.

HAGHI, F. M., AHANJAN, M., ESLAMIFAR, M., AND MOHAMMADI, K. A. 2018.The first report of pathogenic bacteria isolated from blow flies Lucilia sericata (Diptera: Calliphoridae) in Sari city, North of Iran. J. Entomol. Zool. Study. 6(2):2056-2061.

HUMPHREY, T., O'BRIEN, S., and MADSEN, M. 2007. Campylobacters as zoonotic pathogens: a food production perspective. Int. J. Food. Microbiol. 117(3): 237-257.

KUMARASINGHE, S. P. W., KARUNAWEERA, N. D., and IHALAMULLA, R. L. 2000. A study of cutaneous myiasis in Sri Lanka. Int. J. Dermatol. 39(9):689-694.

LEE, H. L. 1996. Recovery of forensically important insect larvae from human cadavers in Malaysia (1993-1996). The Malaysian J. Pathol. 18(2): 125-127.

LEE, H. L., KRISHNASAMY, M., ABDULlAH, A. G., and JEFFERY, J. 2004. Review of forensically important entomological specimens in the period of 1972-2002. Tropic. Biomed. 21(2):69-75.

LIMBAGO, B. 2001. M100-S11, Performance standards for antimicrobial susceptibility testing. Clin Microbiol. Newsl. 23:49.

MALDONADO, M. A., and CENTENO, N. 2003. Quantifying the potential pathogens transmission of the blowflies (Diptera: Calliphoridae). Mem.Inst. Oswaldo Cruz. 98(2): 213-216.

MONZON, R. B., SANCHEZ, A. R., TADIAMAN, B. M., NAJOS, O. A., VALENCIA, E. G., DE RUEDA,R. R., and VENTURA, J. V. 1991. A comparison of the role of Musca domestica (Linnaeus) and Chrysomya megacephala (Fabricius) as mechanical vectors of helminthic parasites in a typical slum area of Metropolitan Manila. Southeast Asian J Trop Med Public Health. 22(2): 222-228. 
PAI, H. H., CHEN, W. C., and PENG, C. F. 2005. Isolation of bacteria with antibiotic resistance from household cockroaches (Periplaneta americana and Blattella germanica). Acta. Tropica. 93(3): 259-265.

PAVA-RIPOLL, M., PEARSON, R. E. G., MILLER, A. K., and ZIOBRO, G. C. 2012. Prevalence andrelative risk of Cronobacter spp., Salmonella spp., and Listeria monocytogenes associated with the body surfaces and guts of individual filth flies. Appl. Environ. Microbiol. 78(22): 78917902.

PELCZAR, M.J., CHAN, E.C.S. and KRIEG, N.R. 1993. Microbiology: Concept and application International edition. McGraw-Hill, USA.

SALES, M. D. S. N., COSTA, G. L. D., and BITTENCOURT, V. R. E. P. 2002. Isolation of fungi in Musca domestica Linnaeus, 1758 (Diptera: Muscidae) captured at two natural breeding grounds in the municipality of Seropédica, Rio de Janeiro, Brazil. Memóriasdo Instituto Oswaldo Cruz. 97(8): 1107-1110.

SUKONTASON, K. L., NARONGCHAI, P., SRIPAKDEE, D., BOONCHU, N., CHAIWONG, T., NGERNKLUN, R., and SUKONTASON, K. 2005. First report of human myiasis caused by Chrysomya megacephala and Chrysomya rufifacies (Diptera: Calliphoridae) in Thailand, and its implication in forensic entomology. J.Medical.Entomol. 42(4): 702-704.

SUKONTASON, K. L., BUNCHOO, M., KHANTAWA, B., PIANGJAI, S., RONGSRIYAM, Y., and SUKONTASON, K. 2007.Comparison between Muscadomestica and Chrysomya megacephala as carriers of bacteria in northern Thailand. Southeast Asian J. Trop.Med. \& Pub. Health. 38(1): 38.

THIRKELL, CE., SLOAN-GARDNER, TS., KACMAREK, MC., and POLKINGHORNE, B. 2018. An outbreak of Bacillus cereus toxin-mediated emetic and diarrhoeal syndromes at a restaurant inCanberra, Australia 2018. Commun Dis Intell.43

ZHANG, J., WANG, J., CHEN, L., YASSIN, A. K., KELLY, P., BUTAYE, P., and WANG, C. 2017. Housefly (Musca domestica) and blow fly (Protophormia terraenovae) as vectors of bacteria carrying colistin resistance genes. Appl. Environ. Microbiol.: 84(1): e01736-17.

(Manuscript received on 10 April, 2021 revised on 30 June, 2021) 